\title{
Formyl Peptide-induced Chemotaxis of Human Polymorphonuclear Leukocytes Does Not Require Either Marked Changes in Cytosolic Calcium or Specific Granule Discharge
}

\author{
Role of Formyl Peptide Receptor Reexpression (or Recycling)
}

\author{
H. Daniel Perez, Fred Elfman, Shelley Marder, Errol Lobo, and Harlan E. Ives \\ Rosalind Russell Arthritis Research Laboratory and Division of Nephrology, Department of Medicine, University of California, \\ San Francisco, and Medical Service, San Francisco General Hospital, San Francisco, California 94110
}

\begin{abstract}
We examined the role of intracellular and extracellular calcium on the ability of human polymorphonuclear leukocytes to migrate chemotactically and reexpress (or recycle) formyl peptide receptors when challenged with the synthetic chemotactic peptide, $\boldsymbol{N}$-formyl-methionyl-leucyl-phenylalanine (FMLP). Extracellular calcium was not required for either optimal chemotactic responses or receptor reexpression. Depletion and chelation of intracellular calcium resulted in significant diminution in the ability of polymorphonuclear leukocytes to release the specific granule constituents lactoferrin and vitamin $\mathrm{B}_{12}$-binding protein during the process of chemotaxis, but had no effect on the capability of these cells to respond chemotactically. Similarly, chelation of intracellular calcium did not affect the ability of these cells to reexpress a population of formyl peptide receptors. Inhibition of receptor reexpression, by a nonagglutinating derivative of wheat-germ agglutinin, was associated with inhibition of chemotactic responses to FMLP. Thus, it appears that large changes in cytosolic free calcium are not necessary for formyl peptide-induced polymorphonuclear leukocyte chemotaxis. In contrast, continuous reexpression (or recycling) of formyl peptide receptors is required for polymorphonuclear leukocyte chemotactic responses to FMLP, a process that appears to be independent from specific granule fusion with plasma membrane.
\end{abstract}

\section{Introduction}

When human polymorphonuclear leukocytes (PMN) are exposed to the synthetic chemotactic factor $N$-formyl-methionyl-leucyl-phenylalanine (FMLP), these cells are stimulated to migrate in a directed fashion (i.e., respond chemotactically) (1, 2). Previously, we reported that FMLP-induced PMN chemotaxis may require the reexpression (or recycling) of a population of FMLP receptors (3). Incubation of PMN with a nonagglutinating derivative of wheat-germ agglutinin (termed

Address reprint requests to Dr. Perez, Building 30, Room 3300, San Francisco General Hospital, 1001 Potrero Avenue, San Francisco, CA 94110.

Received for publication 26 July 1988 and in revised form 30 January 1989.

J. Clin. Invest.

(c) The American Society for Clinical Investigation, Inc.

$0021-9738 / 89 / 06 / 1963 / 08 \$ 2.00$

Volume 83, June 1989, 1963-1970
WGA-D) ${ }^{1}$ specifically inhibited FMLP-induced PMN chemotaxis $(3,4)$. WGA-D was capable of inhibiting reexpression (or recycling) of a population of FMLP receptors by PMN without interfering with the ability of these cells to release specific granules constituents (i.e., degranulate) during the process of reexpression (3). These results suggested that reexpression of FMLP receptors (and perhaps chemotactic responsiveness to FMLP) by PMN was not dependent upon extensive degranulation (5).

We have used the highly selective calcium $\left(\mathrm{Ca}^{2+}\right)$ probe fura 2 to examine the role of changes in cytosolic free $\mathrm{Ca}^{2+}$ $\left(\left[\mathrm{Ca}^{2+}\right]_{\mathrm{i}}\right)$ and degranulation on FMLP-induced PMN chemotaxis. We found that depletion and chelation of $\left[\mathrm{Ca}^{2+}\right]_{i}$, while inhibiting degranulation of migrating PMN, have no effect on the ability of these cells to respond chemotactically toward suboptimal and optimal concentrations of FMLP. Also, PMN loaded with fura 2 acetoxymethyl ester (fura 2-AM) and suspended in low $(0.01 \mathrm{mM}) \mathrm{Ca}^{2+}$ buffer, were able to reexpress FMLP receptors. WGA-D was capable of inhibiting both FMLP-induced PMN chemotaxis as well as receptor reexpression by PMN loaded with fura 2-AM and suspended in low $\mathrm{Ca}^{2+}$ buffer.

Thus, it appears that marked changes in $\left[\mathrm{Ca}^{2+}\right]_{\mathrm{i}}$ are not required for FMLP-induced PMN chemotaxis. Furthermore, the data suggest that degranulation does not modulate the chemotactic responsiveness of PMN to suboptimal and optimal concentrations of FMLP.

\section{Methods}

Preparation of leukocyte suspensions. Platelet-poor leukocyte suspensions containing 97-99\% PMN were prepared from venous blood (50 $\mathrm{ml}$ ), obtained from healthy adult volunteers, that had been mixed with $12 \mathrm{ml}$ of acid-citrate dextrose, as described (4).

Loading of PMN with fura 2-AM. Pure PMN were incubated at $37^{\circ} \mathrm{C}$ for $60 \mathrm{~min}$ with fura 2-AM (Molecular Probes, Inc., Junction City, OR) in low $(0.01 \mathrm{mM}) \mathrm{Ca}^{2+}$ buffer (phosphate $10 \mathrm{mM}$-buffered $140 \mathrm{mM} \mathrm{NaCl}, \mathrm{pH} 7.4$ ) (PBS), containing $0.5 \%$ bovine serum albumin that had been spun at $100,000 \mathrm{~g}$ to remove aggregates, and had been pretreated with Chelex-100 (Bio-Rad Laboratories, Richmond, CA) to remove residual $\mathrm{Ca}^{2+}$. Control PMN were subjected to the same manipulations in the absence of fura 2-AM. After loading, PMN were washed once in low $\mathrm{Ca}^{2+}$ buffer and resuspended at a concentration of $2 \times 10^{6}$ cells $/ \mathrm{ml}$ in either low $(0.01 \mathrm{mM})$ or high $(1.3 \mathrm{mM}) \mathrm{Ca}^{2+}$ buffer (PBS supplemented with $\mathrm{Ca}^{2+}$ ). The fluorescent intensity of PMN loaded with fura 2-AM was monitored (excitation wavelengths 335 and $380 \mathrm{~nm}$, emission wavelength $510 \mathrm{~nm}$ ) using a ratio spectroflu-

1. Abbreviations used in this paper: fura 2-AM, fura 2 acetoxymethyl ester; WGA-D, wheat-germ agglutinin derivative. 
orometer (SLM Instruments, Inc., Urbana, IL) with temperature control and stirring attachments (6). Upon stimulation with FMLP, changes in fluorescence at 335 and $380 \mathrm{~nm}$ were determined and the ratio $(R)$ at $335 / 380 \mathrm{~nm}$ was determined. The dye response was calibrated by lysis of the cells (using $0.1 \%$ Triton X-100) into buffer containing $1.3 \mathrm{mM} \mathrm{Ca}^{2+}$. Fluorescence ratio $\left(R_{\mathrm{s}}\right)$ was determined, $5.0 \mathrm{mM}$ EGTA (final pH 8.7) was added, and fluorescence ratio $\left(R_{\mathrm{o}}\right)$ was again determined. $\left[\mathrm{Ca}^{2+}\right]_{\mathrm{i}}$ was calculated using the formula $\left[\mathrm{Ca}^{2+}\right]_{\mathrm{i}}=K(R$ $\left.-R_{\mathrm{o}} / R_{\mathrm{s}}-R\right)(6)$, where $K=k_{\mathrm{d}}\left(F_{\mathrm{o}} / F_{\mathrm{s}}\right)$. The $k_{\mathrm{d}}$ was $224 \mathrm{nM}$, and $F_{\mathrm{s}}$ and $F_{\text {o }}$ were fluorescent intensities of the lysed cells at $380 \mathrm{~nm}$ excitation in $1.3 \mathrm{mM} \mathrm{Ca}^{2+}$ and $5.0 \mathrm{mM}$ EGTA (pH 8.7), respectively.

$P M N$ chemotaxis and degranulation. Stimulated random motility (chemokinesis) and directed migration (chemotaxis) of PMN were measured using a minor modification (7) of the "leading front" method of Zigmond and Hirsch (8). Results are reported as the distance (micrometers per $35 \mathrm{~min}$ ) that the leading front of cells migrated into $3.0-\mu \mathrm{m}$ pore diameter cellulose nitrate micropore filters (Sartorius Filters, Inc., San Francisco, CA) separating the upper, or cell compartments, from the lower, or stimulus compartments, of modified Boyden chambers. Chemotaxis (net migration) was calculated by substracting stimulated random motility from total migration. Duplicate chambers were used in each experiment and 10 fields examined in each filter.

Extracellular release of the specific granule markers vitamin $\mathbf{B}_{12-}$ binding protein and lactoferrin, was assessed using minor modifications of previously described methods $(4,6)$. Results for vitamin $B_{12^{-}}$ binding protein are expressed as picograms of vitamin $\mathbf{B}_{12}$-binding protein per milliliter, and for lactoferrin as nanograms of lactoferrin released per milliliter.

Assays using $\left[{ }^{3} H\right] F M L P$. In some experiments, we examined the ability of normal and fura 2-AM-loaded PMN to recover their ability to bind $\left[{ }^{3} \mathrm{H}\right] \mathrm{FMLP}$, using a minor modification of the methods described previously (3). Briefly, PMN $\left(5 \times 10^{6}\right.$ cells $\left./ \mathrm{ml}\right)$ suspended in buffer were incubated at $37^{\circ} \mathrm{C}$ for 5 min with $50 \mathrm{nM}$ unlabeled FMLP (Peninsula Laboratories, Inc., San Carlos, CA). After preincubation cells were washed once at $4^{\circ} \mathrm{C}$, resuspended in prewarmed buffer $(16$ $\left.\times 10^{6} \mathrm{PMN} / \mathrm{ml}\right)$ and aliquots $(0.25 \mathrm{ml})$ incubated at $37^{\circ} \mathrm{C}$ for varying durations. Reactions were stopped by the addition of equal volumes of $4^{\circ} \mathrm{C}$ buffer containing $20 \mathrm{nM}\left[{ }^{3} \mathrm{H}\right] \mathrm{FMLP}$ (sp act $48.5 \mathrm{Ci} / \mathrm{mmol}$ ) (New England Nuclear, Boston, MA). PMN were incubated with $\left[{ }^{3} \mathrm{H}\right] \mathrm{FMLP}$ for $10 \mathrm{~min}$ on ice to achieve equilibrium binding (4) and pelleted through oil, and the pellets were processed as described previously (3). Nonspecific binding, that is, binding not inhibited by 1,000 -fold excess unlabeled FMLP, represented 8-10\% of total binding.

Subcellular distribution of $\left[{ }^{3} \mathrm{H}\right] \mathrm{FMLP}$ within normal and WGA-D-treated PMN was assessed as desctibed previously (3). PMN $\left(6 \times 10^{8}\right.$ cells) were suspended in $0.01 \mathrm{mM}\left[\mathrm{Ca}^{2+}\right](5.0 \mathrm{ml})$ containing $50 \mathrm{nM}\left[{ }^{3} \mathrm{H}\right] \mathrm{FMLP}$ and $10 \mu \mathrm{g} / \mathrm{ml}$ each of superoxide dismutase and catalase, and incubated at either 4 or $37^{\circ} \mathrm{C}$ for 5 or $20 \mathrm{~min}$, in the presence and absence of WGA-D. Reactions were stopped by the addition of equal volumes of $4^{\circ} \mathrm{C}$ buffer. PMN were washed twice with $4^{\circ} \mathrm{C} 0.01 \mathrm{mM}\left[\mathrm{Ca}^{2+}\right]$ buffer, resuspended in $14 \mathrm{ml}$ of $4^{\circ} \mathrm{C} 0.01 \mathrm{mM}$ $\left[\mathrm{Ca}^{2+}\right]_{0}$ buffer, pH 7.4, containing $0.34 \mathrm{M}$ sucrose, $1.0 \mathrm{mM}$ EDTA, 10 $\mathrm{mM}$ Hepes, and $1.0 \mathrm{mM}$ diisopropylfluorophosphate (Sigma Chemical Co., St. Louis, MO) (cavitation buffer). Suspended PMN were subjected to nitrogen cavitation at $4^{\circ} \mathrm{C}$, and supernatants containing $75-85 \%$ of all markers fractionated on linear (15-60\%) sucrose density gradients, as described previously (3). Recovery of markers was between 85 and $95 \%$ of the amount present in starting supernatants. Lactic dehydrogenase (cytoplasmic marker), $\beta$-glucuronidase (azurophilic granule marker), vitamin $B_{12}$-binding protein (specific granule marker), alkaline phosphatase (plasma membrane marker), uridinediphosphate-galactose galactosyl transferase (Goigi marker), protein content, and $\left[{ }^{3} \mathrm{H}\right] \mathrm{FMLP}$-associated radioactivity were determined as described previously (3).

Right-angle scattering. Analysis of right-angle scattering, performed on PMN suspensions containing $4 \times 10^{6}$ cells $/ \mathrm{ml}$, was done using a ratio spectrofluorometer (SLM Instruments, Inc.) interfaced with a model XT computer (IBM Instruments, Inc., Danbury, CT) (excitation and emmision wavelength $340 \mathrm{~nm}$ ) (9). Cell responses were monitored continuously, under constant stirring at $37^{\circ} \mathrm{C}$.

\section{Results}

To determine the role of $\mathrm{Ca}^{2+}$ in FMLP-induced PMN chemotaxis, we used concentrations of fura 2-AM that buffer PMN $\left[\mathrm{Ca}^{2+}\right]_{\mathrm{i}}(6)$. Loading of PMN with fura 2-AM $(10 \mu \mathrm{M})$ resulted in an intracellular concentration of dye of $0.6-0.8$ $\mathrm{mM}$. As reported previously (6), under these loading conditions PMN $\left[\mathrm{Ca}^{2+}\right]_{\mathrm{i}}$ was depleted. Baseline $\left[\mathrm{Ca}^{2+}\right]_{\mathrm{i}}$ was $12.8 \pm 1.7$ $\mathrm{nM}$ (mean $+\mathrm{SE}, n=7$ ). Stimulation of $\mathrm{PMN}$ with $10^{-7} \mathrm{M}$ FMLP raised $\left[\mathrm{Ca}^{2+}\right]_{i}$ to $36.8 \pm 2.8 \mathrm{nM}$, indicating that marked changes in cytosolic $\mathrm{Ca}^{2+}$ did not occur within these cells upon stimulation. Resuspension of fura 2-AM-loaded PMN in 1.3 $\mathrm{mM}\left[\mathrm{Ca}^{2+}\right]_{0}$ results in a rapid (within $60 \mathrm{~s}$ ) restoration of $\left[\mathrm{Ca}^{2+}\right]_{\mathrm{i}}$ (baseline $67.3 \pm 4.7 \mathrm{nM}$ ) that increases to $438 \pm 12 \mathrm{nM}$ upon stimulation with $10^{-7} \mathrm{M}$ FMLP (6).

$\mathrm{PMN}$ were incubated at $37^{\circ} \mathrm{C}$ for $60 \mathrm{~min}$ in the presence or absence of fura 2-AM, washed, resuspended in either low (i.e., $0.01 \mathrm{mM}\left[\mathrm{Ca}^{2+}\right]_{0}$ ) or high (i.e., $1.3 \mathrm{mM}\left[\mathrm{Ca}^{2+}\right]_{0}$ ) buffer and their ability to respond chemotactically to FMLP determined. In the presence of $1.3 \mathrm{mM}\left[\mathrm{Ca}^{2+}\right]_{0}$, normal PMN (i.e., cells incubated in the absence of fura 2-AM) responded chemotactically when challenged with either suboptimal $\left(10^{-9} \mathrm{M}\right)$ or optimal $\left(10^{-8} \mathrm{M}\right)$ concentrations of FMLP (Fig. $\left.1 A\right)(3)$. Higher concentrations of FMLP $\left(10^{-7}\right.$ to $\left.10^{-6} \mathrm{M}\right)$ resulted in diminished PMN migration, a phenomenon known as deactivation $(3,10)$. When suspended in $0.01 \mathrm{mM}\left[\mathrm{Ca}^{2+}\right]_{0}$, normal $\mathrm{PMN}$ responded as well as $\mathrm{PMN}$ in $1.3 \mathrm{mM}\left[\mathrm{Ca}^{2+}\right]_{0}$ to suboptimal and optimal concentrations of FMLP (Fig. $1 A$ ). Deactivation, however, was not observed until $10^{-6}$ M FMLP was used (Fig. $1 A$ ).

In a second series of experiments, $\mathrm{PMN}\left[\mathrm{Ca}^{2+}\right]_{\mathrm{i}}$ was buffered by the use of fura 2. Upon challenge with $10^{-9}$ to $10^{-8} \mathrm{M}$ FMLP, fura 2-AM-loaded PMN migrated as well as normal PMN when resuspended in either $1.3 \mathrm{mM}\left[\mathrm{Ca}^{2+}\right]_{0}, 0.01 \mathrm{mM}$ $\left[\mathrm{Ca}^{2+}\right]_{0}$, or $0.01 \mathrm{mM}\left[\mathrm{Ca}^{2+}\right]_{\text {o }}$ plus $1.0 \mathrm{mM}$ EGTA (Fig. $1 \mathrm{~B}$ ). FMLP-induced deactivation of fura 2-AM-loaded PMN resuspended in low $\mathrm{Ca}^{2+}$ buffer required 10-fold more FMLP and the degree of deactivation observed at $10^{-6} \mathrm{M}$ FMLP was $30 \%$ less than that observed using normal PMN in low $\mathrm{Ca}^{2+}$ buffer $(P<0.01$, Student's $t$ test). Thus, it appears that neither depletion nor chelation of PMN $\left[\mathrm{Ca}^{2+}\right]_{i}$ has an effect on FMLP-induced chemotaxis. Depletion and chelation of PMN $\left[\mathrm{Ca}^{2+}\right]_{i}$, however, significantly inhibited the process of FMLPinduced deactivation.

Human PMN have an intracellular pool of FMLP receptors which colocalize, on sucrose density gradients, with specific granules (11). It has been suggested that specific granules are the source of this intracellular receptor pool $(11,12)$, and that degranulation during the process of locomotion is a necessary event for continuous expression of FMLP receptors and optimal PMN chemotactic responsiveness to FMLP $(5,13)$. Consequently, we performed experiments to determine the degree of PMN degranulation in the course of the chemotactic assay. Normal and fura 2-AM-loaded PMN were resuspended in either 1.3 or $0.01 \mathrm{mM}\left[\mathrm{Ca}^{2+}\right]_{0}$ and their ability to migrate chemotactically toward increasing concentrations of FMLP was determined (Fig. $2 A$ ). At the end of the chemotactic assay the contents of the upper chambers were removed, layered over silicone oil, and spun at $15,000 \mathrm{~g}$ for $2 \mathrm{~min}$ to remove 


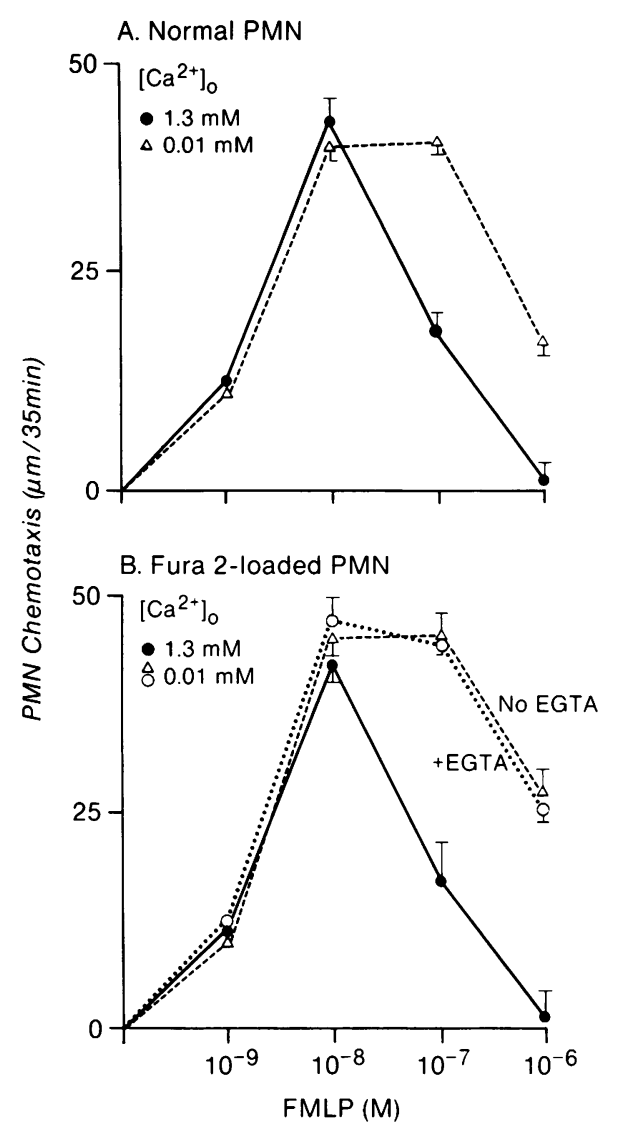

Figure 1. (A) Chemotactic responses of normal PMN that had been preincubated in $0.01 \mathrm{mM}\left[\mathrm{Ca}^{2+}\right]_{\mathrm{o}}$ (loading conditions) and resuspended in either $(\bullet) 1.3$ or $(\Delta) 0.01 \mathrm{mM}\left[\mathrm{Ca}^{2+}\right]_{\mathrm{o}} .(B)$ Chemotactic responses of fura 2-AM-loaded PMN resuspended in either $(\bullet) 1.3$ $\mathrm{mM}\left[\mathrm{Ca}^{2+}\right]_{0},(\Delta) 0.01 \mathrm{mM}\left[\mathrm{Ca}^{2+}\right]_{0}$, or $(0) 0.01 \mathrm{mM}\left[\mathrm{Ca}^{2+}\right]_{0}$ plus 1.0 $\mathrm{mM}$ EGTA. Results represent the mean $( \pm \mathrm{SE})$ of three to five experiments.

residual PMN (3). The cell-free supernatants were then assayed for their contents of the specific granule markers, vitamin $\mathrm{B}_{12}$-binding protein (Fig. $2 \mathrm{~B}$ ) and lactoferrin (Fig. $2 \mathrm{C}$ ). In the presence of $1.3 \mathrm{mM}\left[\mathrm{Ca}^{2+}\right]_{0}$, fura 2-AM-loaded PMN responded chemotactically as well as normal PMN to FMLP (Fig. $2 \mathrm{~A}$ ). Release of specific granules constituents was detected when $10^{-9} \mathrm{M}$ FMLP was present in the lower chamber (Fig. 2, $B$ and $C$ ) and increased as higher concentrations of FMLP were used. Maximal degranulation occurred when $10^{-6}$ M FMLP was present in the lower chamber, a concentration of peptide that completely deactivates PMN (Fig. 2, $A-C$ ). When suspended in $0.01 \mathrm{mM}\left[\mathrm{Ca}^{2+}\right]_{o}$, normal PMN migrated equally well to suboptimal and optimal concentrations of FMLP (Fig. $2 A$ ) in the absence of detectable degranulation (Fig. 2, $B$ and $C$ ). When $10^{-7} \mathrm{M}$ FMLP was used, these cells did not deactivate and exhibited minimal degranulation $(17 \%$ of the degranulation response observed when PMN were suspended in $1.3 \mathrm{mM}\left[\mathrm{Ca}^{2+}\right]_{0}$ ) (Fig. $2, A-C$ ). When $10^{-6} \mathrm{M}$ FMLP was present in the lower chamber, normal PMN suspended in $0.01 \mathrm{mM}\left[\mathrm{Ca}^{2+}\right]_{0}$ exhibited a deactivation (and degranulation response) similar to that observed when normal PMN suspended in $1.3 \mathrm{mM}\left[\mathrm{Ca}^{2+}\right]_{0}$ were exposed to $10^{-7} \mathrm{M}$ FMLP. When suspended in $0.01 \mathrm{mM}\left[\mathrm{Ca}^{2+}\right]_{0}$, fura 2-AM-loaded PMN also migrated normally to suboptimal and optimal con-
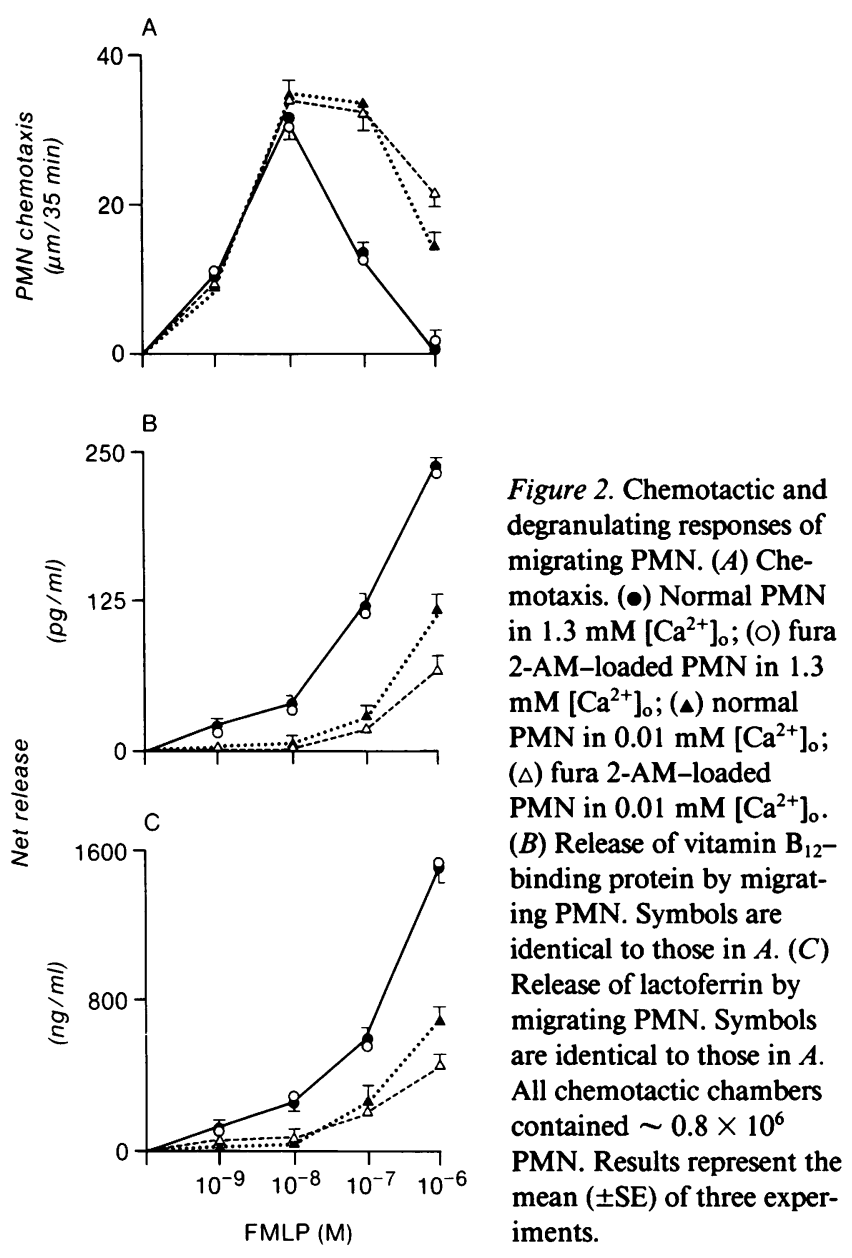

centrations of FMLP (Fig. $2 A$ ) and did not degranulate during the process of chemotaxis (Fig. 2, $B$ and $C$ ). When $10^{-6} \mathrm{M}$ FMLP was used, these cell exhibited less (25\%) deactivation (and degranulation) than normal PMN suspended in low $\mathrm{Ca}^{2+}$ buffer.

Previously, we reported that FMLP-induced PMN chemotaxis may require the continuous reexpression (or recycling) of a population of FMLP receptors $(3,14)$. Thus, it was of interest to determine the ability of normal and fura 2-AM-loaded PMN (suspended in either low or high $\mathrm{Ca}^{2+}$ buffer) to both reexpress FMLP receptors and recover their chemotactic responsiveness to FMLP. Normal and fura 2-AM-loaded PMN were resuspended $\left(37^{\circ} \mathrm{C}, 5 \mathrm{~min}\right)$ in low $\mathrm{Ca}^{2+}$ buffer containing $50 \mathrm{nM}$ unlabeled FMLP, washed $\left(4^{\circ} \mathrm{C}\right)$, and resuspended in prewarmed buffer (either low or high $\mathrm{Ca}^{2+}$ ) and their ability to recover their capacity to bind $\left[{ }^{3} \mathrm{H}\right] \mathrm{FMLP}$ was examined, as described in Methods (3). Preincubation of either normal or fura 2-AM-loaded PMN with unlabeled FMLP resulted in a $60-70 \%$ diminution in their subsequent ability to bind $\left[{ }^{3} \mathrm{H}\right]-$ FMLP (Fig. $3 A$ ), a phenomenon known as down-regulation $(3,15)$. Whereas untreated (i.e., preincubated in the absence of unlabeled FMLP) PMN specifically bound $6.8 \pm 0.15 \times 10^{3}$ molecules of $\left[{ }^{3} \mathrm{H}\right] \mathrm{FMLP} / \mathrm{PMN}$, cells that were preincubated with $50 \mathrm{nM}$ unlabeled FMLP bound $2.9 \pm 0.21 \times 10^{3}$ molecules $\left[{ }^{3} \mathrm{H}\right] \mathrm{FMLP} / \mathrm{PMN}(P<0.01$, Student's $t$ test, $n=3)$. This was true for both normal and fura 2-AM-loaded PMN (Fig. 3 A). After washing and resuspension at $37^{\circ} \mathrm{C}$ in the presence of $1.3 \mathrm{mM}\left[\mathrm{Ca}^{2+}\right]_{0}$, normal and fura 2-AM-loaded PMN rapidly 


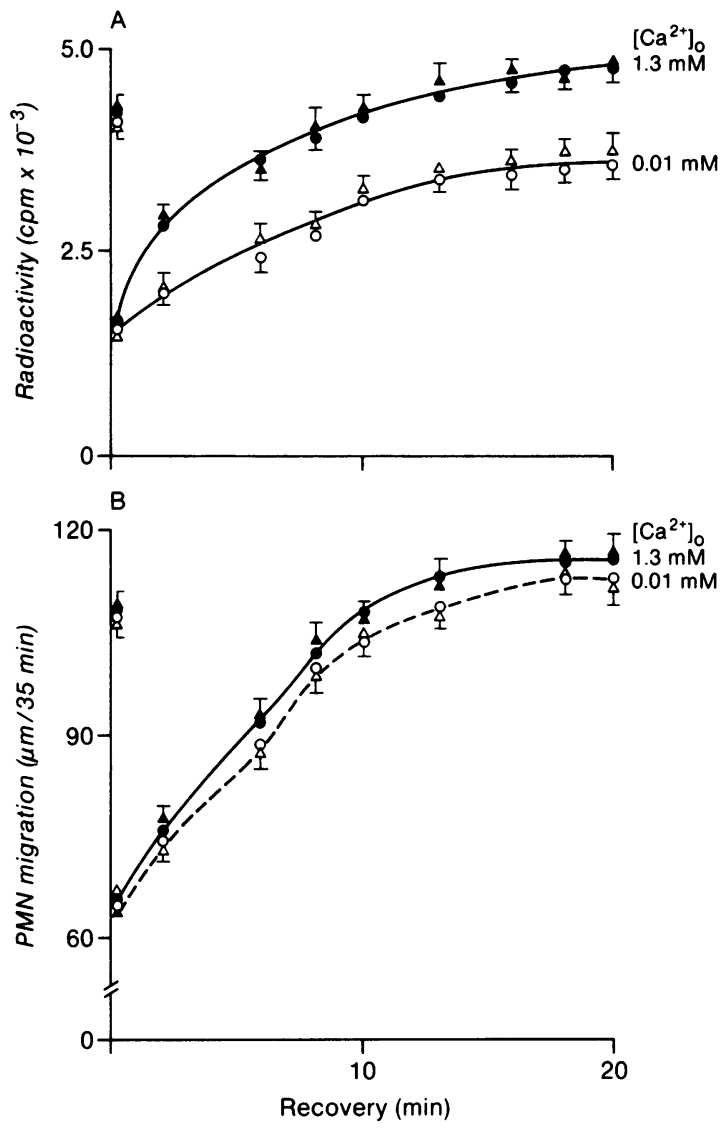

Figure 3. (A) Effect of intra- and extracellular $\mathrm{Ca}^{2+}$ on FMLP receptor reexpression by normal and fura 2-AM-loaded PMN. Assay was performed as described in Methods. At each time point, reactions were stopped by adding equal amounts of cold buffer containing 20 $\mathrm{nM}\left[{ }^{3} \mathrm{H}\right] \mathrm{FMLP}$, and processed as described in Methods. (๑) Normal PMN in $1.3 \mathrm{mM}\left[\mathrm{Ca}^{2+}\right]_{0}$; ( $)$ fura 2-AM-loaded PMN in $1.3 \mathrm{mM}$ $\left[\mathrm{Ca}^{2+}\right]_{0} ;(0)$ normal PMN in $0.01 \mathrm{mM}\left[\mathrm{Ca}^{2+}\right]_{0} ;(\Delta)$ fura 2-AMloaded PMN in $0.01 \mathrm{mM}\left[\mathrm{Ca}^{2+}\right]_{0}$. (B) Effect of intra- and extracellular $\mathrm{Ca}^{2+}$ on FMLP-induced PMN chemotaxis during receptor reexpression. At varying durations during receptor reexpression, reactions were stopped by adding equal volumes of cold buffer. PMN were washed once, resuspended in either low or high $\mathrm{Ca}^{2+}$ buffer, and used for the chemotaxis assays. FMLP was used at a chemoattractant at a final concentration of $10^{-8} \mathrm{M}$. Symbols are identical to those in $A$. Results in $A$ and $B$ represent the mean ( $\pm \mathrm{SE}$ ) of three experiments.

recovered their ability to bind $\left[{ }^{3} \mathrm{H}\right] \mathrm{FMLP}$ (Fig. $3 \mathrm{~A}$ ). After 10 min of incubation, both cell populations bound $\sim 7.1 \pm 0.3$ $\times 10^{3}$ molecules of $\left[{ }^{3} \mathrm{H}\right] \mathrm{FMLP} / \mathrm{PMN}$, a value similar to that observed before incubation with unlabeled FMLP $\left(6.8 \times 10^{3}\right.$ molecules per cell) (Fig. $3 \mathrm{~A}$ ). After $18 \mathrm{~min}$ of incubation at $37^{\circ} \mathrm{C}$, normal and fura 2-AM-loaded PMN (in the presence of $1.3 \mathrm{mM}\left[\mathrm{Ca}^{2+}\right]_{0}$ ) bound $8.2 \pm 0.19 \times 10^{3}$ molecules of $\left[{ }^{3} \mathrm{H}\right]-$ FMLP per cell. Longer incubations did not result in further increments in their binding capacity (3). Thus, normal and fura 2-AM-loaded PMN, when resuspended in high $\mathrm{Ca}^{2+}$ buffer recovered their initial binding capacity within $10 \mathrm{~min}$ of incubation at $37^{\circ} \mathrm{C}$ and after $18 \mathrm{~min}$ bound $\sim 15 \%$ more peptide than PMN preincubated in the absence of unlabeled FMLP (i.e., superrecovery) $(3,15)$. These cells also released $\sim 15 \%$ of their total content of vitamin $B_{12}$-binding protein into supernates during the process of receptor recovery (3).
When normal and fura 2-AM-loaded PMN were washed and incubated at $37^{\circ} \mathrm{C}$ in the presence of $0.01 \mathrm{mM}\left[\mathrm{Ca}^{2+}\right]_{0}$, recovery of their ability to bind $\left[^{3} \mathrm{H}\right] \mathrm{FMLP}$ was observed (Fig. $3 \mathrm{~A}$ ). While the kinetics of recovery appeared similar to that observed in $1.3 \mathrm{mM}\left[\mathrm{Ca}^{2+}\right]_{0}$, after $10 \mathrm{~min}$ of incubation in low $\mathrm{Ca}^{2+}$ buffer normal and fura 2-AM-loaded PMN bound $4.9 \pm 0.1 \times 10^{3}$ molecules of $\left[{ }^{3} \mathrm{H}\right] \mathrm{FMLP} / \mathrm{PMN}$ (vs. $6.8 \pm 0.15$ $\times 10^{3}$ molecules per cell when examined in high $\mathrm{Ca}^{2+}$ buffer) (Fig. $3 \mathrm{~A}$ ). After $18 \mathrm{~min}$ of incubation at $37^{\circ} \mathrm{C}$ in $0.01 \mathrm{mM}$ $\left[\mathrm{Ca}^{2+}\right]_{0}$, normal and fura 2-AM-loaded PMN bound 5.61 \pm 0.2 $\times 10^{3}$ molecules of $\left[{ }^{3} \mathrm{H}\right] \mathrm{FMLP} / \mathrm{PMN}(\sim 30 \%$ less than PMN incubated in $1.3 \mathrm{mM}\left[\mathrm{Ca}^{2+}\right]_{0}$ for $18 \mathrm{~min}$ ) (Fig. $3 \mathrm{~A}$ ). These cells, however, did not release vitamin $B_{12}$-binding protein during the process of receptor recovery. Thus, granule-associated receptor expression (observed in the presence of $1.3 \mathrm{mM}$ $\left.\left[\mathrm{Ca}^{2+}\right]_{0}\right)$ may account for these differences $(11,12)$.

In the same set of experiments we determined the ability of normal and fura 2-AM-loaded PMN that had been preincubated with unlabeled FMLP and allowed to recover for varying periods of time, to respond chemotactically to a subsequent challenge with FMLP $\left(10^{-8} \mathrm{M}\right)$ (Fig. $\left.3 \mathrm{~B}\right)$. At designated time points during recovery, reactions were stopped by the addition of equal volumes of cold $\left(4^{\circ} \mathrm{C}\right)$ low $\mathrm{Ca}^{2+}$ buffer. Cells were washed once and resuspended in either 1.3 or $0.01 \mathrm{mM}\left[\mathrm{Ca}^{2+}\right]_{0}$ buffer containing Chelex-treated bovine serum albumin $(2.0 \%$ $\mathrm{wt} / \mathrm{vol})(6)$.

Normal and fura 2-AM-loaded PMN that had been preincubated with unlabeled FMLP, washed, and resuspended in either low or high $\mathrm{Ca}^{2+}$ buffer were unable, initially, to migrate chemotactically in response to $10^{-8} \mathrm{M}$ FMLP (Fig. $3 \mathrm{~B}$ ). Stimulated random migration in response to albumin-containing buffer was unaffected (not shown). When allowed to recover for $10 \mathrm{~min}$ at $37^{\circ} \mathrm{C}$ (in either 1.3 or $0.01 \mathrm{mM}\left[\mathrm{Ca}^{2+}\right]_{0}$ ), normal and fura 2-loaded PMN exhibited chemotactic responses to FMLP similar to those observed when PMN that had not been preincubated with unlabeled FMLP were used (Fig. $3 B$ ). After 18 min of recovery, normal and fura 2-AM-loaded PMN that had been preincubated with unlabeled FMLP and resuspended in either 1.3 or $0.01 \mathrm{mM}\left[\mathrm{Ca}^{2+}\right]_{0}$ migrated $10 \%$ more than control PMN (i.e., superrecovery). Thus, normal and fura 2-AM-loaded PMN resuspended in $0.01 \mathrm{mM}\left[\mathrm{Ca}^{2+}\right]_{0}$ reexpress $30 \%$ fewer receptors, did not degranulate during recovery, but regained their ability to migrate chemotactically in a normal fashion.

To assess whether receptor reexpression by fura 2-AMloaded PMN resuspended in $0.01 \mathrm{mM}\left[\mathrm{Ca}^{2+}\right]_{0}$ was associated with FMLP-induced chemotaxis, experiments were performed using WGA-D. Previously, we reported that WGA-D inhibits FMLP-induced PMN chemotaxis by blocking the reexpression of a population of formyl peptide receptors (3). Normal and fura 2-AM-loaded PMN in $0.01 \mathrm{mM}\left[\mathrm{Ca}^{2+}\right]_{0}$ were preincubated with $50 \mathrm{nM}$ unlabeled FMLP and $3.0 \mu \mathrm{g} / \mathrm{ml}$ WGA-D for $5 \mathrm{~min}$ at $37^{\circ} \mathrm{C}$ and washed with cold low $\mathrm{Ca}^{2+}$ buffer, and receptor reexpression and chemotactic recovery were assessed as described above.

In the presence of $1.3 \mathrm{mM}\left[\mathrm{Ca}^{2+}\right]_{0}$, WGA-D inhibited reexpression of FMLP receptors by fura 2-AM-loaded PMN by $\sim 40 \%$ (Fig. $4 A$ ). This is similar to what we reported previously using normal PMN (3). Inhibition of receptor reexpression was associated with inhibition of chemotactic recovery (legend to Fig. 4). When normal and fura 2-AM-loaded PMN were resuspended in $0.01 \mathrm{mM}\left[\mathrm{Ca}^{2+}\right]_{0}$ (after exposure to 

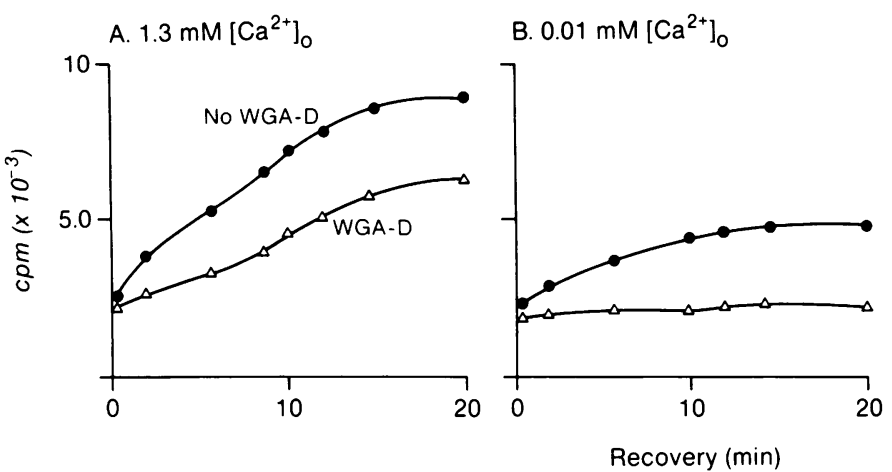

C. $0.01 \mathrm{mM}\left[\mathrm{Ca}^{2+}\right]_{0}$

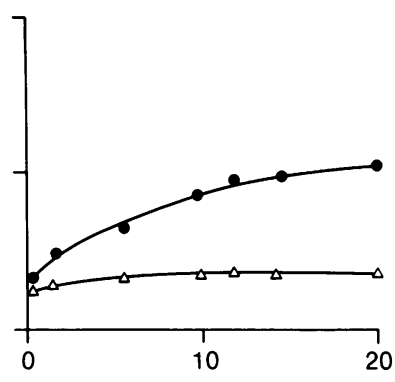

Figure 4. Effect of WGA-D on FMLP receptor reexpression. $(A)$ Receptor reexpression by fura 2-AM-loaded PMN suspended in $1.3 \mathrm{mM}\left[\mathrm{Ca}^{2+}\right]_{0}$ in the $(\Delta)$ presence and $(\bullet)$ absence of WGA-D. (B) Receptor reexpression by normal PMN suspended in $0.01 \mathrm{mM}$ $\left[\mathrm{Ca}^{2+}\right]_{0}$ in the $(\Delta)$ presence and $(\bullet)$ absence of WGA-D. $(C)$ Receptor reexpression by fura 2-AM-loaded PMN suspended in $0.01 \mathrm{mM}$ $\left[\mathrm{Ca}^{2+}\right]_{0}$ in the $(\Delta)$ presence and $(\bullet)$ absence of WGA-D. Chemotactic responses after $18 \mathrm{~min}$ of incubation were $(A)$ no WGA-D, $122.3 \mu \mathrm{m} / 35 \mathrm{~min}$; WGA-D treated, $87.4 \mu \mathrm{m} / 35 \mathrm{~min} ;(B)$ no WGA-D, $124.8 \mu \mathrm{m} / 35$ min; WGA-D treated, $85.6 \mu \mathrm{m} / 35 \mathrm{~min}$; $(C)$ no WGA-D, $123.9 \mu \mathrm{m} / 35 \mathrm{~min}$; WGA-D treated, $88.1 \mu \mathrm{m} / 35 \mathrm{~min}$. Stimulated random migration was $85.2 \mu \mathrm{m} / 35 \mathrm{~min}$ and was unaffected by WGA-D (4). Results are the average of two experiments performed in duplicate.

unlabeled FMLP and WGA-D), WGA-D-treated cells failed to reexpress FMLP receptors (Fig. $4, B$ and $C$ ) and did not respond chemotactically when challenged with $10^{-8} \mathrm{M}$ FMLP (legend to Fig. 4).

If WGA-D inhibits reexpression of FMLP receptors by PMN, exposure of cells to $\left[{ }^{3} \mathrm{H}\right] \mathrm{FMLP}$ in the presence of WGA-D should result in intracellular accumulation of $\left[{ }^{3} \mathrm{H}\right]-$ FMLP-associated radioactivity (some of which represent peptide-receptor complexes) (3). Consequently, we performed experiments to examine the subcellular distribution of $\left[{ }^{3} \mathrm{H}\right]-$ FMLP-associated radioactivity within $\mathrm{Ca}^{2+}$-depleted $\mathrm{PMN}$, in the presence and absence of WGA-D. PMN $\left(6 \times 10^{8}\right.$ cells) isolated in low $\mathrm{Ca}^{2+}$ buffer (i.e., $\mathrm{Ca}^{2+}$-depleted $\mathrm{PMN}$ ) were suspended in $5.0 \mathrm{ml}$ of $0.01 \mathrm{mM}\left[\mathrm{Ca}^{2+}\right]_{\mathrm{o}}$ buffer and incubated ( 5 or $15 \mathrm{~min}$ ) in the presence of either $\left[{ }^{3} \mathrm{H}\right] \mathrm{FMLP}(50 \mathrm{nM})$ or $\left[{ }^{3} \mathrm{H}\right]$ FMLP and WGA-D $\left(1.0 \mu \mathrm{g} / 10^{6} \mathrm{PMN}\right)$ at 4 and $37^{\circ} \mathrm{C}$. After incubation, reactions were stopped by the addition of equal volumes of $4^{\circ} \mathrm{C}$ low $\mathrm{Ca}^{2+}$ buffer. PMN were washed, resuspended in cavitation buffer, disrupted by $\mathrm{N}_{2}$ cavitation and fractionated on linear sucrose density gradients, as described in Methods (3). Incubation of PMN $\left(4^{\circ} \mathrm{C}, 5 \mathrm{~min}\right)$ with $\left[{ }^{3} \mathrm{H}\right]$ FMLP resulted in a peak of radioactivity comigrating with the plasma membrane marker, alkaline phosphatase (Fig. $5 \mathrm{~A}$ ). These counts represented bound but not internalized peptide. Similar results were obtained if WGA-D was present during the incubation (Fig. $5 \mathrm{~A}$ ).

When incubated with $\left[{ }^{3} \mathrm{H}\right] \mathrm{FMLP}$ at $37^{\circ} \mathrm{C}$ for $5 \mathrm{~min}$ (Fig. 5 $B$ ), PMN internalized a fraction of the peptide to a compartment with a density lower than the plasma membrane marker alkaline phosphatase, and comigrating with the Golgi marker galactosyl transferase. A small but reproducible amount of radioactivity was detected in the lysosomal (vitamin $B_{12}$-binding protein) compartment (3). When identical experiments were performed in the presence of WGA-D, PMN accumulated $\sim 25-30 \%$ more radioactivity in both the Golgi and lysosomal compartments (Fig. $5 B$ and Table I). Radioactivity present within Golgi fractions remained sedimentable $(83 \%$ after $100,000 \mathrm{~g}$ for $180 \mathrm{~min}$ ) after sonication of the samples at $4^{\circ} \mathrm{C}$ for $2 \mathrm{~min}$ (3). Radioactivity in lysosomal compartment became nonsedimentable after sonication. After $20 \mathrm{~min}$ of incubation at $37^{\circ} \mathrm{C}$ with $\left[{ }^{3} \mathrm{H}\right]$ FMLP, WGA-D-treated PMN had $40 \%$ more sedimentable radioactivity within light Golgi fractions and $50 \%$ more nonsedimentable counts within the lysosomal fractions (Table I).
PMN chemotactic responsiveness requires actin polymerization and depolymerization (16). Sklar et al. (9) reported that the decrease in right-angle scatter observed when PMN are stimulated with formyl peptide correlates with actin polymerization. Thus, it was of interest to assess the ability of fura 2-AM-loaded PMN resuspended in either 1.3 or $0.01 \mathrm{mM}$ $\left[\mathrm{Ca}^{2+}\right]_{0}$ to undergo changes in right-angle scatter in response to suboptimal and deactivating concentrations of FMLP (Fig. 6). When stimulated with $10^{-9}$ M FMLP, fura 2-AM-loaded PMN (suspended in either 1.3 or $0.01 \mathrm{mM}\left[\mathrm{Ca}^{2+}\right]_{0}$ ) exhibited a rapid ( $\left.t_{\frac{1}{2}} 12 \mathrm{~s}\right)$ decrease in right-angle scatter (i.e., actin polymerization) (9) followed by a slower $\left(t_{\frac{1}{2}} 14 \mathrm{~s}\right)$ recovery (i.e., actin depolymerization) (9) (Fig. $6 A$ ). This response did not require large changes in $\left[\mathrm{Ca}^{2+}\right]_{\mathrm{i}}(9,17)$ and exhibited identical kinetics as those reported previously (9). When a second pulse of FMLP $\left(10^{-9} \mathrm{M}\right)$ was given at $120 \mathrm{~s}$, both cell types again

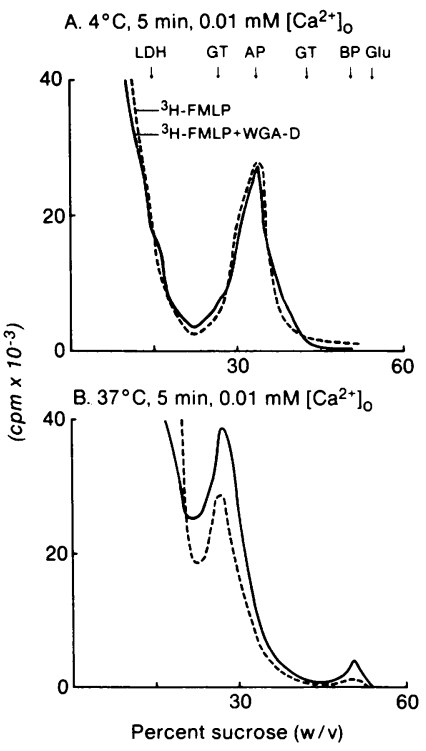

Figure 5. Subcellular distribution of $\left[{ }^{3} \mathrm{H}\right] \mathrm{FMLP}$-associated radioactivity within control and WGA-D-treated PMN. Cells $\left(6 \times 10^{8} \mathrm{PMN}\right)$ were incubated with $50 \mathrm{nM}\left[{ }^{3} \mathrm{H}\right]-$ FMLP, in the presence and absence of WGA-D (as described in Methods and Results), washed, disrupted by $\mathrm{N}_{2}$ cavitation, and fractionated on linear sucrose density gradients as described in Methods. Distribution of radioactivity after (A) 5 min of incubation with either (---) $\left[{ }^{3} \mathrm{H}\right] \mathrm{FMLP}$ alone or $(-)\left[{ }^{3} \mathrm{H}\right] \mathrm{FMLP}+$ WGA-D at $4^{\circ} \mathrm{C},(B) 5 \mathrm{~min}$ of incubation with either $(---)\left[{ }^{3} \mathrm{H}\right]-$ FMLP alone or $(\longrightarrow)\left[{ }^{3} \mathrm{H}\right]-$ FMLP + WGA-D at $37^{\circ} \mathrm{C}$. Recovery of radioactivity from gradients (counts per minute per milligram of protein) and specific markers was virtually identical for control and WGA-D-treated PMN. Subcellular markers: LDH, lactate dehydrogenase; GT, UDPgalactose galactosyl transferase; AP, alkaline phosphatase; BP, vitamin $B_{12}$-binding protein; Glu, $\beta$-glucuronidase. One of two experiments with essentially identical results. 
Table I. Subcellular Distribution of $\left[{ }^{3} \mathrm{H}\right] F M L P$ within Control and WGA-D-treated PMN

\begin{tabular}{lcccc}
\hline & \multicolumn{4}{c}{ Radioactivity* } \\
\cline { 2 - 5 } & & \multicolumn{3}{c}{ Granules } \\
\cline { 3 - 5 } \cline { 3 - 4 } & Cytosol & Golgi & Specific & Azurophilic \\
\hline & \multicolumn{5}{c}{$c p m \times 10^{-3}$} \\
5 min & 78.1 & 2.7 & 0.67 & 0.15 \\
PMN & 77.3 & 3.6 & 0.93 & 0.13 \\
PMN + WGA-D & & & & \\
20 min & 331.6 & 13.3 & 0.95 & 0.25 \\
PMN & 320.3 & 21.0 & 2.1 & 0.31 \\
PMN + WGA-D & & & & \\
\end{tabular}

* Results represent radioactivity in peak fractions obtained from experiments performed as described in Methods. Cytosol refers to fractions containing maximum lactate dehydrogenase activity. Golgi refers to light Golgi fractions containing maximum UDP-galactose galactosyl transferase activity. Specific granules refers to fractions containing maximum vitamin $B_{12}$-binding protein activity, and azurophilic granules refers to fractions containing maximum $\beta$-glucuronidase activity. One of two experiments with essentially identical results.

exhibited a rapid diminution in right-angle scatter but the $t_{1}$ decreased from 12 to $4 \mathrm{~s}$ (Fig. $6 \mathrm{~A}$ ). Interestingly, the $t_{1}$ of recovery for fura 2-AM-loaded PMN suspended in $0.01 \mathrm{mM}$ $\left[\mathrm{Ca}^{2+}\right]_{0}$ was $16 \mathrm{~s}$ (i.e., similar to that observed during the first FMLP pulse) while the $t_{1}$ of recovery for fura 2-loaded PMN suspended in $1.3 \mathrm{mM}\left[\mathrm{Ca}^{2+}\right]_{0}$ was 32 s (i.e., a 2.2 -fold increment as compared to the first pulse) (Fig. $6 \mathrm{~A}$ ).

When identical experiments were performed using $10^{-7} \mathrm{M}$ FMLP, we again observed differences between the two cell preparations (Fig. $6 \mathrm{~B}$ ). Upon initial stimulation with $10^{-7} \mathrm{M}$ FMLP, fura 2-AM-loaded PMN suspended in either 1.3 or $0.01 \mathrm{mM}\left[\mathrm{Ca}^{2+}\right]_{\mathrm{o}}$ had a rapid diminution in right-angle scatter $\left(t_{\frac{1}{2}} 5 \mathrm{~s}\right)$ followed by a slower recovery $\left(t_{1} 22 \mathrm{~s}\right)(9)$. However, upon a second pulse, fura 2-AM-loaded PMN suspended in $0.01 \mathrm{mM}\left[\mathrm{Ca}^{2+}\right]_{0}$ exhibited a diminution in right-angle scatter with a $t_{1}$ of $2 \mathrm{~s}$ (vs. $5 \mathrm{~s}$ in the presence of $1.3 \mathrm{mM}\left[\mathrm{Ca}^{2+}\right]_{0}$ ) followed by a recovery exhibiting a $t_{1}$ of $20 \mathrm{~s}$ (vs. an incomplete recovery with a $t_{\frac{1}{2}}$ of $55 \mathrm{~s}$ in the presence of $1.3 \mathrm{mM}\left[\mathrm{Ca}^{2+}\right]_{0}$ ) (Fig. 6 B).

\section{Discussion}

Results presented here indicate that neither large changes in $\left[\mathrm{Ca}^{2+}\right]_{i}$ nor fusion of specific granules with plasma membrane are required for FMLP-induced PMN chemotaxis (Figs. 1 and 2). Under the loading conditions used here (either in the presence or absence of $10 \mu \mathrm{M}$ fura 2-AM) PMN $\left[\mathrm{Ca}^{2+}\right]_{\mathrm{i}}$ is depleted, as we demonstrated previously using a wide range of concentrations of fura 2-AM during loading (6). Furthermore, fura 2-AM (10 $\mu \mathrm{M})$-loaded PMN suspended in $0.01 \mathrm{mM}\left[\mathrm{Ca}^{2+}\right]_{0}$ exhibit minimal increments in $\left[\mathrm{Ca}^{2+}\right]_{\mathrm{i}}$ when stimulated with $10^{-7} \mathrm{M}$ FMLP (6), indicating chelation of PMN $\left[\mathrm{Ca}^{2+}\right]_{\mathrm{i}}$ by intracellular fura 2-AM. Normal and fura 2-AM-loaded PMN resuspended in $0.01 \mathrm{mM}\left[\mathrm{Ca}^{2+}\right]_{0}$ however, behaved as well as $\left[\mathrm{Ca}^{2+}\right]_{\mathrm{i}}$-repleted PMN (normal and fura 2-AM-loaded) with

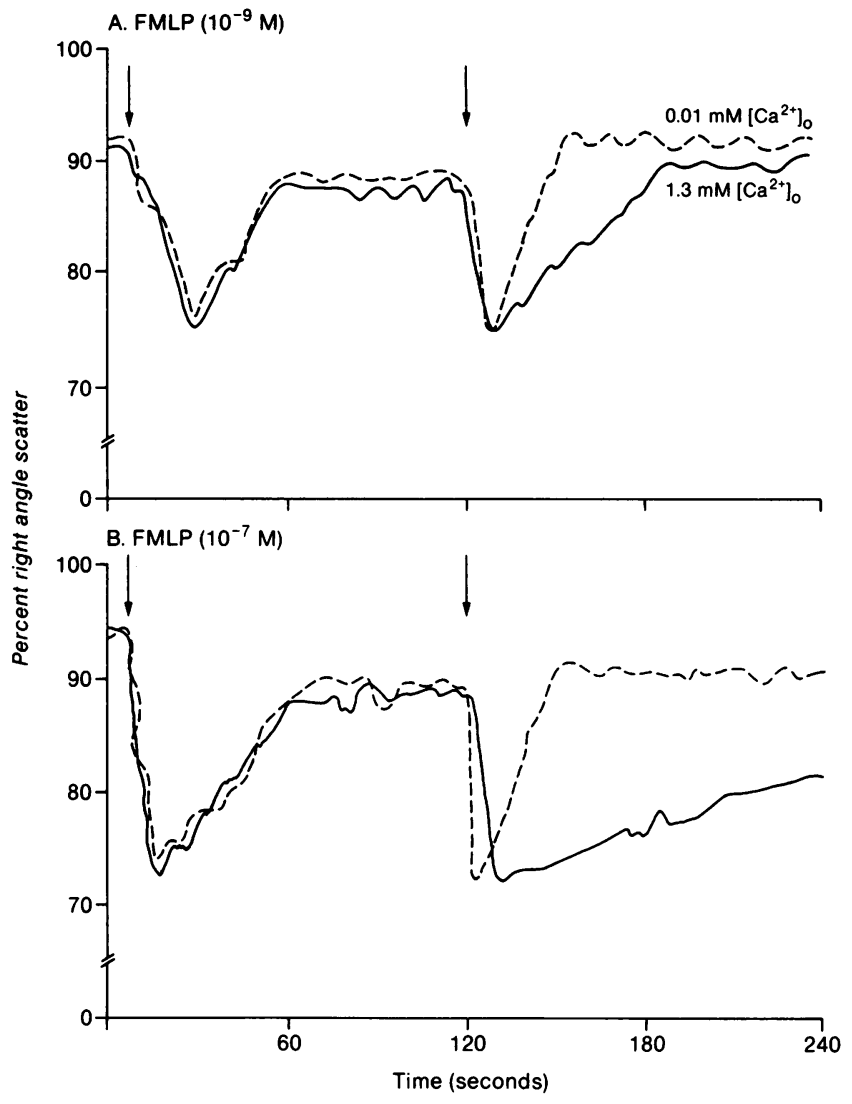

Figure 6. Right-angle scatter responses of fura 2-AM-loaded PMN stimulated with FMLP at 0 and 120 s. $(A) 10^{-9}$ M FMLP: (---) fura 2-AM-loaded PMN suspended in $0.01 \mathrm{mM}\left[\mathrm{Ca}^{2+}\right]_{0} ;(-)$ fura 2-AM-loaded PMN suspended in $1.3 \mathrm{mM}\left[\mathrm{Ca}^{2+}\right]_{0}$. (B) $10^{-7} \mathrm{M}$ FMLP: (---) fura 2-AM-loaded PMN suspended in $0.01 \mathrm{mM}$ $\left[\mathrm{Ca}^{2+}\right]_{0} ;(-)$ fura 2-AM-loaded PMN suspended in $1.3 \mathrm{mM}\left[\mathrm{Ca}^{2+}\right]_{0}$.

respect to their ability to respond chemotactically to suboptimal and optimal concentrations of FMLP (Figs. 1 and 2). Chelation of residual extracellular $\mathrm{Ca}^{2+}(\cong 10 \mu \mathrm{M})$ by excess EGTA $(1.0 \mathrm{mM})$ had no effect on their chemotactic responsiveness (Fig. $1 B$ ) indicating that $\mathrm{Ca}^{2+}$ influx is not required during the process of FMLP-induced PMN directed migration.

These initial findings are in partial agreement with those reported by Meshulan et al. (17). These authors reported that chelation of extracellular $\mathrm{Ca}^{2+}$ by high $(3.6 \mathrm{mM})$ concentrations of EGTA resulted in 30\% inhibition of FMLP-induced PMN chemotaxis, without altering either baseline or FMLPstimulated levels of PMN $\left[\mathrm{Ca}^{2+}\right]_{\mathrm{i}}$. An explanation for our discrepancy was found when we assessed the effect of increasing concentrations of EGTA on the ability of PMN (normal and fura 2-AM-loaded) resuspended in either 1.3 or $0.01 \mathrm{mM}$ $\left[\mathrm{Ca}^{2+}\right]_{0}$ to migrate chemotactically toward either FMLP or highly purified human C5a. At concentrations between 2.0 and $5.0 \mathrm{mM}$, EGTA inhibited, in a concentration-dependent fashion, PMN chemotactic responses to either both stimuli. The concentration of EGTA used in our studies is in vast excess of the available extracellular $\mathrm{Ca}^{2+}$ present in the buffer, as demonstrated by studies in which we titrated $\left[\mathrm{Ca}^{2+}\right]_{0}$ with fura 2-AM and increasing concentrations of EGTA. As expected, complete chelation of $\left[\mathrm{Ca}^{2+}\right]_{0}$ was observed when 10-12 $\mu$ M EGTA was used. Furthermore, incubation of either normal or fura 2-AM-loaded PMN in $0.01 \mathrm{mM}\left[\mathrm{Ca}^{2+}\right]_{0}$ for 60 
min at $37^{\circ} \mathrm{C}$ did not result in significant increment in extracellular $\mathrm{Ca}^{2+}$ (i.e., $\mathrm{Ca}^{2+}$ efflux). Thus, we believe that the discrepancy between our studies and those of Meshulan et al. (17) can be accounted for by toxic effects of high concentrations of EGTA on PMN. These authors also reported that depletion of PMN $\left[\mathrm{Ca}^{2+}\right]_{\mathrm{i}}$ (by chelation with quin 2) resulted in further inhibition of these cells chemotactic responsiveness to FMLP, but still exhibited $\sim 40 \%$ of their control migratory response. Two possible explanation exists for the partial discrepancy between our results and those of Meshulam et al. (17). One is that quin 2 and fura 2-AM chelate different pools of PMN $\left[\mathrm{Ca}^{2+}\right]_{i}$. This seems unlikely since results of studies addressing the role of cytosolic $\mathrm{Ca}^{2+}$ in FMLP-induced PMN degranulation using either quin 2 or fura $2-\mathrm{AM}$ are identical $(6,18)$. The second possibility is that quin 2 or a quin 2 metabolite may affect the ability of PMN to migrate chemotactically, a phenomenon not observed when fura 2-AM is used.

Support for our results indicating that neither $\left[\mathrm{Ca}^{2+}\right]_{\mathrm{o}}$ nor large changes in $\left[\mathrm{Ca}^{2+}\right]_{\mathrm{i}}$ are required for formyl peptide-induced PMN chemotaxis is a report by Zigmond et al. (19), published during the preparation of this manuscript. These authors investigated the role of extracellular and cytosolic $\mathrm{Ca}^{2+}$ on the ability of PMN to migrate chemotactically. Chelation of extracellular $\mathrm{Ca}^{2+}$ had no effect on formyl peptide-induced PMN chemotaxis. Furthermore, depletion of PMN $\left[\mathrm{Ca}^{2+}\right]_{\mathrm{i}}($ by preincubating the cells in EGTA and ionophore-containing buffer) had no effect on PMN chemotactic responsiveness to optimal concentrations of formyl peptide.

An interesting observation in our studies was the association between deactivation of chemotactic responsiveness and release of specific granule components observed using normal and fura 2-AM-loaded PMN resuspended in either 1.3 or 0.01 $\mathrm{mM}\left[\mathrm{Ca}^{2+}\right]_{0}$ (Fig. 2, $A-C$ ). It appears that fusion of specific granules with plasma membrane may play a role in the phenomenon of FMLP-induced PMN deactivation, since similar degrees of degranulation resulted in identical degrees of deactivation (Fig. 2, A-C; normal and fura 2-AM-loaded PMN resuspended in $1.3 \mathrm{mM}\left[\mathrm{Ca}^{2+}\right]_{\mathrm{o}}$ vs. normal PMN resuspended in $0.01 \mathrm{mM}\left[\mathrm{Ca}^{2+}\right]_{0}$ ). Further inhibition of degranulation (Fig. 2, $A-C$; fura 2-AM-loaded PMN vs. normal PMN both resuspended in $0.01 \mathrm{mM}\left[\mathrm{Ca}^{2+}\right]_{0}$ ) resulted in diminished deactivation. Degranulation may play a role in deactivation perhaps by allowing expression of adhesive glycoproteins (stored within specific granules) on the cell surface (20). Increased PMN adhesiveness would result in diminished migration, a phenomenon reported by us previously (21). An alternative explanation for our results would be that both processes (i.e., degranulation during migration and deactivation) are unrelated but have similar dependence on PMN $\left[\mathrm{Ca}^{2+}\right]_{i}$.

To examine the role of $\left[\mathrm{Ca}^{2+}\right]_{i}$ and degranulation on formyl peptide receptor reexpression (or recycling), normal and fura 2-AM-loaded PMN resuspended in either 1.3 or $0.01 \mathrm{mM}$ $\left[\mathrm{Ca}^{2+}\right]_{0}$ were incubated with $50 \mathrm{nM}$ FMLP at $37^{\circ} \mathrm{C}$ for $5 \mathrm{~min}$. This concentration of FMLP was chosen because it completely abolished (initially) PMN chemotactic responsiveness to FMLP (Fig. $3 \mathrm{~B}$ ) and resulted in a $70 \%$ diminution of FMLP binding at zero time (Fig. $3 A$ ). These results suggested that neither binding of FMLP to its receptor nor internalization of FMLP-receptor complexes $(3,14)$ by PMN was dependent upon extracellular or intracellular $\mathrm{Ca}^{2+}$.

After incubation, PMN were washed, resuspended in either 1.3 or $0.01 \mathrm{mM}\left[\mathrm{Ca}^{2+}\right]_{0}$ buffer and their ability to bind $\left[{ }^{3} \mathrm{H}\right]$ -
FMLP specifically examined (Fig. 3 A) (3). It should be noted that there was no loss of intracellular fura 2 during these incubations, as determined by cell lysis in $\mathrm{Ca}^{2+}$-containing buffer.

As expected, normal and fura 2-AM-loaded PMN resuspended in $1.3 \mathrm{mM}\left[\mathrm{Ca}^{2+}\right]_{0}$ reexpressed formyl peptide receptors in a time-dependent fashion (Fig. $3 A$ ) (3), a process that was accompanied by significant ( $\cong 15 \%$ of total) release of vitamin $B_{12}$-binding protein. When resuspended in $0.01 \mathrm{mM}$ $\left[\mathrm{Ca}^{2+}\right]_{0}$, normal and fura 2-loaded PMN were capable of reexpressing $\sim 75-80 \%$ of their original binding sites (Fig. $3 \mathrm{~A}$ ) in the absence of detectable release of either vitamin $B_{12}$-binding protein or lactoferrin. The kinetics of recovery of binding were similar for PMN resuspended in either high or low $\mathrm{Ca}^{2+}$ (Fig. $3 \mathrm{~A}$ ). The degree of receptor reexpression however, was different. After a 20-min recovery, normal and fura 2-loaded PMN resuspended in $0.01 \mathrm{mM}\left[\mathrm{Ca}^{2+}\right]_{0}$ reexpressed $\sim 35-40 \%$ fewer binding sites than PMN resuspended in $1.3 \mathrm{mM}\left[\mathrm{Ca}^{2+}\right]_{0}$. This difference may represent the lack of expression of an intracellular pool of receptors by PMN resuspended in low $\mathrm{Ca}^{2+}$ buffer $(11,12)$.

In spite of the differences in receptor reexpression, normal and fura 2-AM-loaded PMN when resuspended in either 0.01 or $1.3 \mathrm{mM}\left[\mathrm{Ca}^{2+}\right]_{0}$ exhibited the same degree of recovery of chemotactic responsiveness to $10^{-8} \mathrm{M}$ FMLP (Fig. $3 \mathrm{~B}$ ). This phenomenon indicates that the increased number of receptors reexpressed by PMN in the presence of $1.3 \mathrm{mM}\left[\mathrm{Ca}^{2+}\right]_{0}$ do not play a role in mediating FMLP-induced chemotaxis.

Experiments performed using WGA-D (Fig. 4, $A-C$ ) demonstrated that at least some of the population of formyl peptide receptors reexpressed by normal and fura 2-AM-loaded PMN resuspended in $0.01 \mathrm{mM}\left[\mathrm{Ca}^{2+}\right]_{0}$ was required for these cells to migrate chemotactically. Inhibition of reexpression resulted in inhibition of FMLP-induced PMN chemotaxis (Fig. $4, A-C)$. Thus, by eliminating the contribution of $\mathrm{Ca}^{2+}$-dependent expression of FMLP binding sites (Fig. 4, $B$ and $C$ ) we were able to assess only receptor reexpression.

Previously, we reported that WGA-D binds to a site on the PMN membrane that exhibits the same molecular weight as the FMLP receptor (3). Furthermore, the affinity-labeled FMLP receptor can be immunoprecipitated by incubation with WGA and anti-WGA antibody (22). Also, WGA-D is not internalized by PMN unless the cells are stimulated with FMLP (3). Since specific granule fusion with plasma membrane is not detectable under these conditions (Fig. 4, $B$ and $C$ ), the most likely explanation for the effect of WGA-D on receptor reexpression is inhibition of receptor recycling. Thus, these experiments indicate that receptor recycling is a prerequisite for FMLP-induced PMN chemotaxis. Receptor recycling occurs without large changes in PMN cytosolic $\mathrm{Ca}^{2+}$ and appears to be independent from specific granule fusion with plasma membrane (12).

Further support for the contention that WGA-D inhibits FMLP receptor reexpression was obtained by the use of subcellular fractionation (Fig. 5, Table I). WGA-D-treated PMN retained more radioactivity in both Golgi and lysosomal fractions. Retention of radioactivity by WGA-D-treated PMN in sedimentable, light Golgi fractions most likely represents $\left[{ }^{3} \mathrm{H}\right]$ FMLP-receptor complexes $(3,14)$. This process will lead to retention of receptors intracellularly, a phenomenon that could manifest itself by diminished reexpression of FMLP receptors on the PMN membrane (i.e., diminished recycling). The increase in nonsedimentable radioactivity in the lyso- 
somal compartment could be due to degradation of ligand-receptor complexes associated with WGA-D. Experiments using ${ }^{125} \mathrm{I}-W \mathrm{~W} A-\mathrm{D}$ demonstrated that ${ }^{3} \mathrm{H}$ and ${ }^{125} \mathrm{I}$ counts comigrated in both Golgi and lysosomal compartments (not shown).

Formyl peptide-induced PMN chemotaxis requires the continuous occupancy of a population of receptors. Occupancy of such receptors initiates the phenomenon of actin polymerization required for PMN continuous directed migration. Several studies have indicated that formyl peptide-induced PMN actin polymerization occurs independently of large changes in $\left[\mathrm{Ca}^{2+}\right]_{\mathrm{i}}$. A recent report also indicated that, in macrophages, actin depolymerization can occur via a $\mathrm{Ca}^{2+}$-independent mechanism (23). Since right-angle scatter can be used as a measurement of actin polymerization and depolymerization (9), we assessed the role of PMN $\left[\mathrm{Ca}^{2+}\right]_{\mathrm{i}}$ on PMN right-angle scatter induced by FMLP pulses (Fig. 6, $A$ and $B$ ) using suboptimal $\left(10^{-9} \mathrm{M}\right)$ and deactivating $\left(10^{-7} \mathrm{M}\right)$ concentrations of peptide. The most striking finding in these studies was the delayed (Fig. $6 \mathrm{~A}$ ) and incomplete (Fig. $6 \mathrm{~B}$ ) depolymerization observed when $\mathrm{Ca}^{2+}$-repleted PMN were subjected to a second pulse of FMLP. Incomplete actin depolymerization (observed when $10^{-7}$ M FMLP was used) may contribute, in part, to the deactivation response observed in $\mathrm{Ca}^{2+}$-repleted cells. Thus, it would appear that the phenomenon of FMLPinduced PMN deactivation is multifactorial.

In summary, our studies demonstrate that large changes in cytosolic $\mathrm{Ca}^{2+}$ are not required for FMLP-induced PMN chemotaxis. The process of PMN directed migration is dependent upon formyl peptide receptor recycling, a process that occurs independently from specific granule fusion with plasma membrane. We conclude that specific granules do not play a role in modulating chemotactic responses of PMN to suboptimal and optimal concentrations of FMLP.

\section{Acknowledgments}

This work was supported by grants from the National Institutes of Health (AM-28566, DK-34127, DE-08138) and funds from the National Dairy Board (administered in cooperation with the National Dairy Council), and performed during the tenure by $\mathrm{H}$. Daniel Perez of an Established Investigatorship from the American Heart Association.

\section{References}

1. Schiffmann, E., B. A. Corcoran, and S. M. Wahl. 1975. $N$-formylmethionyl peptides as chemoattractants for leukocytes. Proc. Natl. Acad. Sci. USA. 72:1059-1062.

2. Becker, E. L. 1976. Some interrelations of neutrophil chemotaxis, lysosomal enzyme release and phagocytosis as revealed by synthetic peptides. Am. J. Pathol. 85:385-394.

3. Perez, H. D., F. Elfmamn, E. Lobo, L. Sklar, D. Chenoweth, and C. Hooper. 1986. A derivative of wheat germ agglutinin specifically inhibits formyl peptide-induced polymorphonuclear leukocyte chemotaxis by blocking re-expression (or recycling) of receptors. J. Immunol. 136:1803-1812.

4. Perez, H. D., F. Elfman, D. Chenoweth, and C. Hooper. 1986. Preparation and characterization of a derivative of wheat germ agglutinin which specifically inhibits polymorphonuclear leukocyte chemotaxis to the synthetic chemotactic peptide $N$-formyl-methionyl-leucylphenylalanine. J. Immunol. 136:1813-1819.
5. Gallin, J. I., D. G. Wright, and E. Schiffmann. 1978. Role of secretory events in modulating human neutrophil chemotaxis. J. Clin. Invest. 62:1364-1374.

6. Perez, H. D., S. Marder, F. Elfman, and H. Ives. 1987. Human neutrophils contain subpopulations of specific granules exhibiting different sensitivities to changes in cytosolic free calcium. Biochem. Biophys. Res. Commun. 145:976-981.

7. Perez, H. D., M. Lipton, and I. M. Goldstein. 1978. A specific inhibitor of complement (C5)-derived chemotactic activity in serum from patients with systemic lupus erythematosus. J. Clin. Invest. 62:29-38.

8. Zigmond, S. H., and J. G. Hirsch. 1973. Leukocyte locomotion and chemotaxis: new methods for evaluation and demonstration of a cell-derived chemotactic factor. J. Exp. Med. 137:387-410.

9. Sklar, L. A., G. M. Omann, and R. G. Painter. 1985. Relationship of actin polymerization and depolymerization to light scattering in human neutrophils: Dependence on receptor occupancy and intracellular $\mathrm{Ca}^{2+}$. J. Cell Biol. 101:1161-1166.

10. Zigmond, S. H. 1981. Consequences of chemotactic peptide receptor modulation for leukocyte orientation. J. Cell Biol. 88:644647.

11. Fletcher, M. P., and J. I. Gallin. 1983. Human neutrophils contain an intracellular pool of putative receptors for the chemoattractant $N$-formyl-methionyl-leucyl-phenylalanine. Blood. 62:792799.

12. Fletcher, M. P., and J. I. Gallin. 1980. Degranulating stimuli increase the availability of receptors for the chemoattractant fmet-leuphe. J. Immunol. 124:1585-1588.

13. Fletcher, M. P., B. Seligmann, and J. I. Gallin. 1982. Correlation of human neutrophil secretion, chemoattractant receptor mobilization and enhanced functional capacity. J. Immunol. 128:941-948.

14. Perez, H. D., F. Elfman, and E. Lobo. 1987. Removal of human polymorphonuclear leukocyte surface sialic acid inhibits reexpression (or recycling) of formyl peptide receptors. J. Immunol. 139:19781984.

15. Zigmond, S. H., S. J. Sullivan, and D. A. Lauffenburger. 1982. Kinetic analysis of chemotactic receptor modulation. J. Cell Biol. 92:34-43.

16. Southwick, F. S., and T. P. Stossel. 1983. Contractile proteins in leukocyte function. Semin. Hematol. 20:305-321.

17. Meshulam, T., P. Proto, R. D. Diamond, and D. A. Melnick. 1986. Calcium modulation and chemotactic response: Divergent stimulation of neutrophil chemotaxis and cytosolic calcium response by the chemotactic peptide receptor. J. Immunol. 137:1954-1960.

18. Lew, D., A. Monod, F. A. Waldvogel, B. Dewald, M. Baggiolini, and T. Pozzan. 1986. Quantitative analysis of the cytosolic free calcium dependency of exocytosis from three subcellular compartments in intact human neutrophils. J. Cell Biol. 102:2197-2204.

19. Zigmond, S. H., J. L. Sloczewski, M. M. Wilde, and M. Carson. 1988. Polymorphonuclear leukocyte locomotion is insensitive to lowered cytoplasmic calcium levels. Cell Motil. Cytoskeleton. 9:184-189.

20. O'Shea, J. C., C. S. Brown, B. E. Seligmann, J. F. Metcalf, M. M. Frank, and J. I. Gallin. 1985. Evidence for distinct intracellular pools of receptors for $\mathrm{C} 3 \mathrm{~b}$ and $\mathrm{C} 3 \mathrm{bi}$ in human neutrophils. J. Immunol. 134:2580-2587.

21. Charo, I. F., C. Yuen, H. D. Perez, and I. M. Goldstein. 1986. Chemotactic peptides modulate adherence of human polymorphonuclear leukocytes to monolayers of cultured endothelial cells. J. Immunol. 136:3412-3419.

22. Painter, R. G., M. Schmitt, A. J. Jesaitis, L. A. Sklar, K. Preissner, and C. G. Cochrane. 1982. Photoaffinity labeling of the $\mathrm{N}$-formyl peptide receptor of human polymorphonuclear leukocytes. J. Cell. Biochem. 20:203-214.

23. Chaponnier, C., H. L. Yin, and T. P. Stossel. 1987. Reversibility of gelsolin/actin interaction in macrophages. J. Exp. Med. 165:97106. 